\title{
First report of dwarf monocle bream Parascolopsis capitinis (Teleostei: Nemipteridae) from South-west coast of India
}

Rekha J. Nair, Dinesh Kumar and Somy Kuriakose

\begin{abstract}
The dwarf monocle breams of Genus Parascolopsis are bottom living small fishes generally seen in the outer shelf and continental slope waters and are represented worldwide by 12 species. Morphometric measurements, meristic counts and identification of the specimens follows standard methods. Parascolopsis capitinis Russell (J South Asian Nat Hist. 2:63-6, 1996), is reported for the first time from Indian waters based on 22 specimens (192-232 mm total length) collected from Cochin fisheries harbour in the South-west coast of India on 5 November 2012. This is the first report of the fish from Indian waters and adds to the five species already reported from this genus from Indian waters. Full description of the species is provided.
\end{abstract}

Keywords: Nemipteridae, Parascolopsis new record, Indian waters, Water temperature

\section{Introduction}

Dwarf monocle breams (Genus Parascolopsis) are bottom living small fishes, generally seen in the outer shelf and continental slope waters with soft bottom at depths up to 500. Genus Parascolopsis have been previously assigned to the genus Scolopsis, but later Boulenger (1901) proposed the genus name Parascolopsis for his new species Parascolopsis townsendi, based on specimens collected in 360-409 $\mathrm{m}$ in the Gulf of Oman. Parascolopsis capitinis is reported to be distributed throughout the tropical Indo-West Pacific, ranging from Western Indian Ocean (including Red Sea and Persian Gulf) to North East Australia as far as South Japan and southwards to Delagoa Bay on the coast of East Africa (Russell \& Golani 1993). P. capitinis is distinguished by its relatively large head, moderately long pelvic fins, which reach almost up to the vent; and by a black spot on the upper base of the pectoral fin (Russell et al. 1990. Twelve species of Parascolopsis have been recorded worldwide- P. aspinosa (Rao \& Rao), from

\footnotetext{
* Correspondence: rekhacmfri@gmail.com

Central Marine Fisheries Research Institute, Kochi, Kerala, India
}

the Western Indian Ocean, P. baranesi Russell \& Golani, from northern Gulf of Aqaba and Northern Arabian Sea (Nair et al. 2012), P. boesemani (Rao \& Rao), from India; P. capitinis Russell, from St John's Fish Market, Colombo, Sri Lanka, P. eriomma (Jordan \& Richardson) and P. inermis Schlegel in Temminck \& Schlegel, both widespread in the IndoWest Pacific; P. melanophrys Russel \& Chin, from two specimens collected from Kupang, West Timor, Indonesia and Taiwan, on the east coast of Sabah, Malaysia; P. qantasi Russell \& Gloerfelt-Tarp, from Indonesia; $P$. rufomaculatus Russell, from Northwestern Australia; P. tanyactis Russell and P. tosensis (Kamohara) both widespread in the Western Pacific; and P. townsendi Boulenger, from the Western Indian Ocean (Russell \& Golani, 1993; Russell \& Chin, 1996).

\section{Material and methods}

Twenty two specimens of $P$. capitinis were collected from Cochin Fisheries Harbour $\left(9^{0} 29^{\prime} 57^{\prime}{ }^{\prime} \mathrm{N} 74^{\circ} 48^{\prime}\right.$ 05' 'E and $\left.9^{0} 51^{\prime} 05^{\prime \prime} \mathrm{N} 75^{\circ} 26^{\prime} 23^{\prime \prime} \mathrm{E}\right)$ on the South-west coast of India on 5 November 2012. The fishes were identified on the field, photographed (Fig. 1) and 


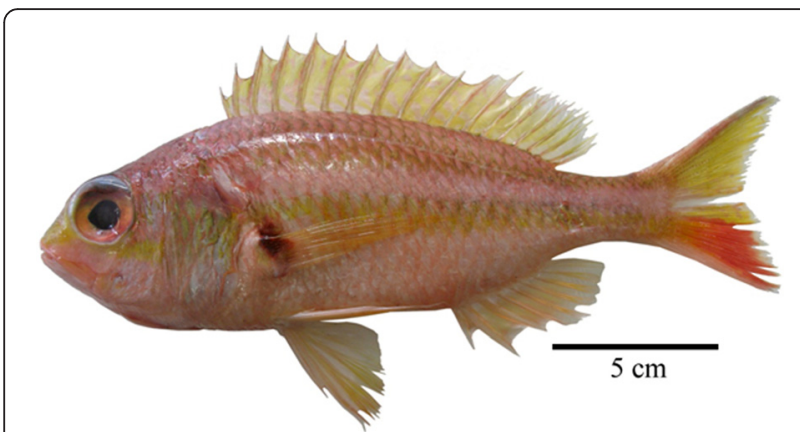

Fig. 1 Parascolopsis capitinis Russell 1996 of 226 mm total length collected from Cochin Fisheries Harbour, Kerala, India

deposited at the National Marine Biodiversity Referral Museum at the Central Marine Fisheries Research Institute, Kochi (GB.31.9.82.4). The fishes were caught by gill netters operating off Cochin at depth range between 50-80 m. Morphometric measurements,

Table 1 Comparision of present specimen, Parascolopsis capitinis Russell 1996 with their holotype and paratypes

\begin{tabular}{|c|c|c|}
\hline Characters & $\begin{array}{l}\text { Holotype and Paratypes } \\
\text { (Russell 1996) }\end{array}$ & $\begin{array}{l}\text { Present Specimens } \\
\text { Kochi }^{\mathrm{a}}\end{array}$ \\
\hline Dorsal fin & $X, 9$ & $X, 9$ \\
\hline Anal fin & III, 7 & III, 7 \\
\hline Pectoral fin & $17(16-17)$ & $17(15-18)$ \\
\hline Lateral line scales & $35(35-36)$ & $35(35-37)$ \\
\hline Gill rakers & $12(11-12)$ & $12(12-13)$ \\
\hline Body depth in SL & $2.9(2.8-3.1)$ & $2.9(2.7-3.0)$ \\
\hline Head length in SL & $2.8(2.6-2.8)$ & $2.8(2.6-3.0)$ \\
\hline Head length in BD & $1(0.9-1.0)$ & $0.9(0.9-1.0)$ \\
\hline Snout in head & $3.6(4.1-4.7)$ & $5.2(3.9-6.2)$ \\
\hline Eye diameter in head & $3.1(2.7-3.1)$ & $3.2(3.0-3.5)$ \\
\hline Eye diameter in snout & $0.9(0.6-0.7)$ & $0.6(0.5-0.8)$ \\
\hline Inter orbital width in ED & $1.5(1.4-1.8)$ & $1.3(1.1-1.6)$ \\
\hline Dorsal fin base length in SL & $1.9(1.9-2.0)$ & $1.8(1.8-1.9)$ \\
\hline $\begin{array}{l}1^{\text {st }} \text { dorsal spine in longest } \\
\text { dorsal spine }\end{array}$ & $1.9(1.9-2.0)$ & $2.1(1.8-2.8)$ \\
\hline $\begin{array}{l}\text { Longest dorsal spine in } \\
\text { longest dorsal ray }\end{array}$ & $1.1(1.0-1.1)$ & $1.1(0.9-1.2)$ \\
\hline Anal fin base length in SL & $6.1(5.9-6.4)$ & $5.8(5.3-6.1)$ \\
\hline $\begin{array}{l}1^{\text {st }} \text { anal spine in } 2^{\text {nd }} \text { anal } \\
\text { spine }\end{array}$ & $1.7(1.6-1.8)$ & $1.8(1.6-2.2)$ \\
\hline $\begin{array}{l}2^{\text {nd }} \text { anal spine in } 3^{\text {rd }} \text { anal } \\
\text { spine }\end{array}$ & $1(0.9-1.0)$ & $1(0.9-1.1)$ \\
\hline Pectoral fin in head & $1.3(1.3-1.4)$ & $1.3(1.2-1.4)$ \\
\hline Pelvic fin in head & $1.5(1.5-1.6)$ & $1.5(1.4-1.6)$ \\
\hline
\end{tabular}

${ }^{\text {a }}$ The measurements given first (outside brackets) are total average of measurements meristic counts (Table 1) and identification of the specimens follows Russell \& Chin (1996).

\section{Results \\ ORDER PERCIFORMES \\ FAMILY NEMIPETRIDAE \\ GENUS PARASCOLOPSIS \\ SPECIES CAPITINIS \\ Parascolopsis capitinis}

Fig. 1

\section{Material described}

Twenty two specimens of $P$. capitinis (GB.31.9.82.4) in the length range 150-181 SL and weighing 96-177 g were collected from Cochin fisheries harbour on the South-west coast of India on 5 November 2012 (Fig. 2).

\section{Description}

Dorsal fin rays $\mathrm{X}, 9$; anal fin rays III, 7; pectoral fin rays 17 (15-18); pelvic fin rays V, 5; lateral-line scales 35 (35-37); gill rakers 12 (12-13). Body moderately deep, depth 2.9 (2.7-3.0) times in SL; body depth equal to or slightly shorter than head length; dorsal head profile slightly convex in front of eye; head length 2.8 (2.6-3.0) times in SL; eyes moderate, placed at the upper edge of dorsal profile, diameter 3.2 (3.0-3.5) times in HL; snout moderately short, $5.2(3.9-6.2)$ times in head; mouth moderate, terminal, maxillary reaches the level of anterior margin of pupil; teeth on jaws villiform. Single dorsal fin; spinous dorsal fin notched, $4^{\text {th }}$ or $5^{\text {th }}$ spine longest $5.5(4.8-7.3)$ times in $\mathrm{HL} ; 2^{\text {nd }}$ or $3^{\text {rd }}$ anal spine longest 2.9 (2.5-3.4) times in HL; long elongated pectoral fin, reaching upto or beyond the level of anal fin orgin; pelvic fins slightly long, filamentous tip reaches vent; caudal peduncle length $2.3(2.0-2.7)$ times in HL. Caudal fin emarginated to slightly forked.

Body rosy pink with traces of indistinct olive band on upper body along lateral line, paling ventrally. An indistinct olive to yellow horizontal stripe from posterior edge of operculum to base of caudal fin. A yellowish band on snout in front of eye. Upper base of pectoral fin with brownish to black spot. Operculum and pre-operculum with traces of yellow band. Caudal fin yellow on the upper half and mild red lower lobe. Dorsal, anal and pelvic fin pinkish with diffused yellow irregular stripes. Pectoral fin translucent yellow.

The maximum reported size of $P$. capitinis is $18.2 \mathrm{~cm}$ SL (Russell, 1996). The size range of the specimens reported here are $170 \mathrm{~mm}$ (150-181) SL weighting $154 \mathrm{~g}$ (96-177). Sex of the fish was determined. Of the total 22 specimens examined, nine were male and 13 female, rest were immature. The gut of most of the fishes were empty with only traces of digested matter; only some 


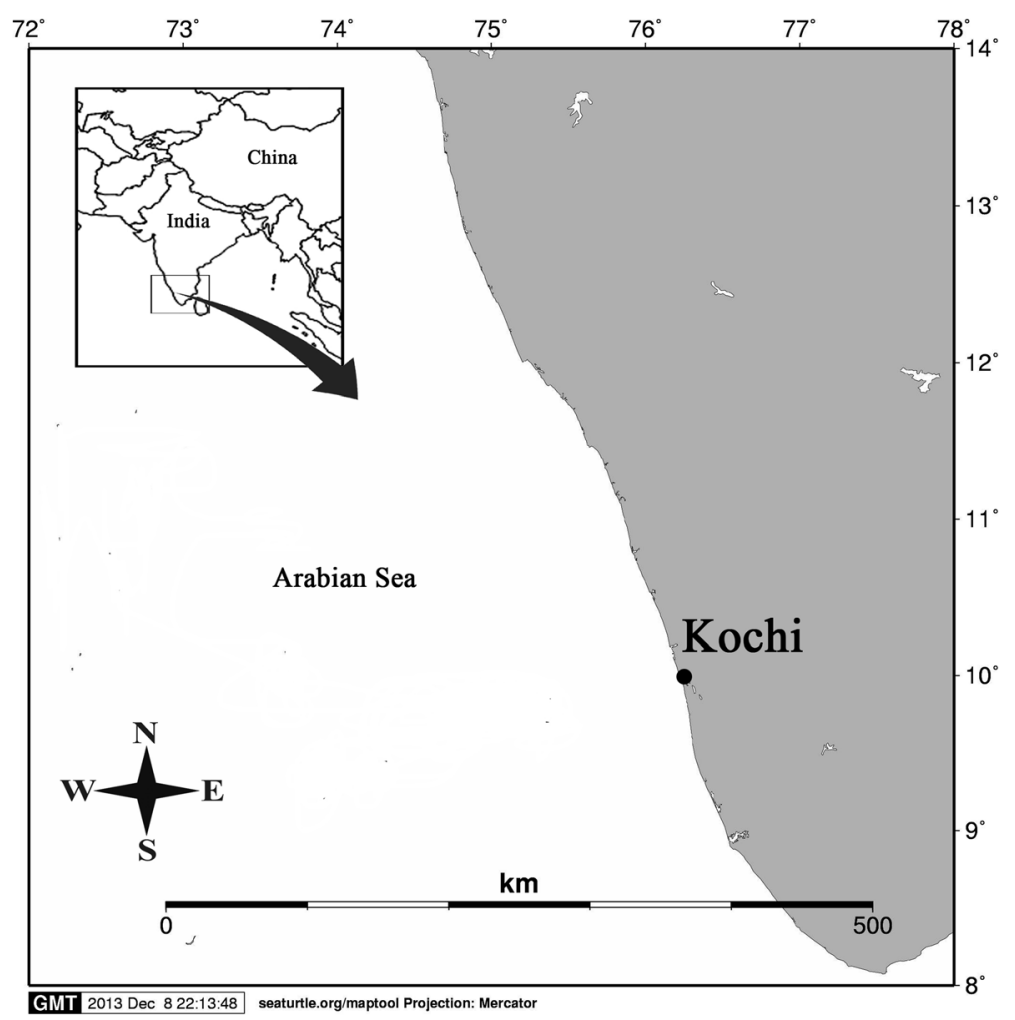

Fig. 2 Southwest coast of India

fish's guts had half-digested parts of shrimps, Acetes, crabs and fishes.

\section{Remarks}

Parascolopsis eriomma is the only similar species in Indian waters but it differs from $P$. captinis by having 17-19 gill rakers on first arch (vs. 11-12); relatively smaller head (head length $3.0-3.3$ in SL, vs $2.6-2.8$ in $\mathrm{SL}$ ); pectoral fins just short to the level of anus (vs. reaching to or beyond level of anal fin origin). Browinish black spot on the upper base of pectoral fin absent in $P$. eriomma (present in P. captinis) (Russell 1996). Caudal fin yellowish (upper half yellow and lower half rosy red). $P$. quantasi the other species which has dark spot on pectoral base is not reported in Indian waters (Russell \& Golani 1993).

\section{Conclusion}

As $P$. captinis is now regularly seen in fishery along with other nemipterid fishes, its presence cannot be attributed to ballast water discharges, but more likely due to effect of climate change, the rise in water temperature, which may have caused the species to move north from Sri Lankan waters to India. The authors agree with the view of Claireaux et al. (1995), that fish often demonstrate avoidance of unfavourable temperatures. The ability to detect and respond to temperature changes can lead to alterations in distribution as fish seek better environmental conditions. The climate changes which led to a rise in the sea surface temperature and therefore coral bleaching during 2004-2005 could have caused the fish to extend its range from native habitat to the west coast of India. The present record is also a pointer to the need for a further taxonomic inventory of the rich reef diversity of Indian waters which may result in recording many more species hitherto not known from Indian waters. Proper identification of organisms is necessary to monitor biodiversity at any level (Vecchione and Collette, 1996). For this, accurate morpho-meristic descriptions are a prerequisite. As more and more range extensions of species are recorded, descriptions of those species have also to be put into place, hence this work acquires its importance.

\section{Abbreviations}

Fig., figure; HL, head length; $S L$, standard length

\section{Acknowledgements}

We are very grateful to the Director, Central Marine Fisheries Research Institute, Kochi and the Heads of Division of Demersal Fisheries and Fishery Resource Assessment for the facilities provided and constant encouragement and support. Many thanks are due to Barry C. Russell for the confirmation of the identification of the fish and their valuable comments. The authors also thank the referees who have greatly contributed to the quality of this manuscript. 


\section{Funding}

The financial support from the Ministry of Environment and Forests is gratefully acknowledged.

\section{Availability of data and materials}

Material was collected from Cochin Fisheries Harbour from landed catch.

\section{Authors' contributions}

RJN and DK did collection, RJN and SK conceived and SK participated in the design of the study. All authors helped to draft the manuscript, read and approved the final manuscript.

\section{Competing interests}

The authors declare that they have no competing interests.

\section{Consent for publication}

I have obtained the necessary consent from my co-authors for publication.

\section{Ethics approval and consent to participate}

No animals were killed or disturbed by me during the study. Study was based on dead animals.

Received: 5 April 2016 Accepted: 28 July 2016

\section{Published online: 05 August 2016}

\section{References}

Boulenger GA. On some deep sea 'fishes collected by Mr. F.W. Townsend in the Sea of Oman. Ann Mag Nat Hist. 1901;7:261-3.

Claireaux G, Webber DM, Kerr SR, Boutilier RG. Physiology and behaviour of freeswimming Atlantic cod Gadus morhua facing fluctuating temperature conditions. J Exp Biol. 1995;198:49-60.

Russell, B.C. FAO Species Catalogue. Vol. 12. Nemipterid fishes of the world. (Threadfin breams, whiptail breams, monocle breams, dwarf monocle breams, and coral breams). Family Nemipteridae. An annotated and illustrated catalogue of nemipterid species known to date. 1990. FAO Fisheries Synopsis 125

Russell BC. Parascolopsis capitinis, a new species of nemipterid fish from Sri Lanka. J South Asian Nat Hist. 1996;2:63-6.

Russell BC, Chin PK. Parascolopsis melanophrys, a new species of dwarf monocle bream (Teleostei: Nemipteridae) from the Indo-Malayan Archipelago. Raffles Bull Zool. 1996;44:415-8.

Russell BC, Golani D. A review of the fish genus Parascolopsis (Nemipteridae) of the Western Indian Ocean, with description of a new species from the northern Red Sea. Israel J Zoo. 1993;39:337-47.

Vecchione M, Collette BB. The central role of systematics in marine biodiversity issues. Oceanography. 1996;9(1):44-9.

\section{Submit your next manuscript to BioMed Central} and we will help you at every step:

- We accept pre-submission inquiries

- Our selector tool helps you to find the most relevant journal

- We provide round the clock customer support

- Convenient online submission

- Thorough peer review

- Inclusion in PubMed and all major indexing services

- Maximum visibility for your research

Submit your manuscript at www.biomedcentral.com/submit
Biomed Central 